\title{
Usefulness of discriminant analysis in the morphofunctional classification of Spanish dog breeds
}

\author{
Ana González', Manuel Luque², Mariano Herrera', Carlos González', Elena Angón and \\ Evangelina Rodero'
}

${ }^{1}$ Animal Production Department, University of Cordoba, Cordoba, Spain, ${ }^{2}$ Spanish Federation of Livestock Purebred Associations (FEAGAS), Madrid, Spain

\begin{abstract}
The aim of this study was to determine whether the classification of local Spanish breeds of dogs, based on morphological traits, matches or differs from the classification based on the dogs' breeding goals. A total of 15 biometric measurements and 10 functional indices were obtained in 1365 dogs (709 females and 656 males). The dogs we measured belonged to 16 different breeds, 14 of which were officially recognized by the Spanish Royal Canine Society. Similar average values of morphometric traits and indices $(P<0.001)$ were obtained in both sexes: the Ratonero Bodeguero Andaluz was the breed with the smallest format and the Pyrenean and Spanish Mastiff, the largest. In the case of the Fédération Cynologique Internationale $(\mathrm{FCl})$ groups, significant differences $(P<0.001)$ for morphometric traits were found, and in both sexes, the third group was the one with the smallest format and the second group, the largest. The differences obtained were more marked between all groups than within groups, and the morphological characteristics were similar, in accordance with the purpose for which the breeds were bred. Therefore, the existence of a morphologic pattern is accepted both in the breeds and the functional groups. Two as yet officially unrecognized breeds, the Orito and Paternino Hound, must be included in the fifth and the first $\mathrm{FCl}$ groups, respectively. When the Orito Hound is recognized, it will be added to the fifth $\mathrm{FCl}$ group and the word »hound « will be deleted from the name Paternino breed.
\end{abstract}

Keywords: morphometric traits, body indices, canine, canonical analysis, $\mathrm{FCl}$ groups

Abbreviations: FCI: Fédération Cynologique Internationale, LOE: Spanish Stud Book, RRC: Registry of Dog Breed, RSCE: Spanish Royal Canine Society

Archiv Tierzucht 57 (2014) 2, 1-16

doi: 10.7482/0003-9438-57-002

Corresponding author:

Ana González; email:v32gomaa@uco.es

University of Cordoba, Animal Production, Campus de Rabanales, Cordoba, 14071 Spain
Received: 4 September 2013

Accepted: 14 January 2014 Online: 11 March 2014

(c) 2014 by the authors; licensee Leibniz Institute for Farm Animal Biology (FBN), Dummerstorf, Germany. This is an Open Access article distributed under the terms and conditions of the Creative Commons Attribution 3.0 License (http://creativecommons.org/licenses/by/3.0/). 


\section{Introduction}

The relationship between body conformation and function has been widely observed for different animal species and breeds (Zaitoun et al. 2005, Yakubu et al. 2010, Latorre et al. 2011).

There are several organizations that control dog breeds (e.g. Fédération Cynologique Internationale $[\mathrm{FCl}]$, the Kennel Club and the American Kennel Club). These organizations are mainly in charge of the taxonomic classification of Canine Species and one of their functions is the characterization, breeding and promotion of dog breeds around the world. In Spain we have the Spanish Royal Canine Society (Real Sociedad Canina Española, RSCE), which has been a member of the $\mathrm{FCl}$ since 1912.

Following the $\mathrm{FCl}$ approach, dog breeds are mainly classified according to the purpose, morphology and kind of work for which they were intended.

In Spain, the approach and rules of the $\mathrm{FCl}$ when classifying and grouping dog breeds are also followed. The RSCE officially recognizes 21 Spanish local breeds of dogs. Nevertheless, only 12 of them are also internationally recognized by the $\mathrm{FCl}$.

In different species of domestic animals, it has been observed that exploratory techniques applied to morphometric variables in domestic animals have allowed us to characterize many breeds and establish differences between populations of sheep (Traoré et al. 2008a, b), goats (Herrera et al. 1996, Dossa et al. 2007), cattle (Yakubu et al. 2010) and dogs (González et al. 2011) and to discriminate analysis methods (simple, stepwise, clustering and canonical) in the morphometric variables, thus allowing for differentiation among breeds and strains within species (Herrera et al. 1996, Capote et al. 1998, Crepaldi et al. 2001, Macciotta et al. 2002, Lanari et al. 2003, Rodero et al. 2003, Zaitoun et al. 2005, Dossa et al. 2007, Marrube et al. 2007, Vargas et al. 2007, Traoré et al. 2008a, b, González et al. 2001).

Several researchers have highlighted the existence of a possible relationship between morphometric traits and the purpose for which a population was bred over the years. There are studies about the characterization and relationship between Spanish dog breeds by morphological characters (Jordana et al. 1992a), biochemical polymorphism (Jordana et al. 1991, Jordana et al. 1992b, c), random amplified polymorphic DNA markers (Morera Sanz et al. 2001), microsatellite markers (Morera et al. 1999) and biometric traits (González et al. 2011). However, there has been no research into the relationship between body conformation and function in Spanish dog breeds.

The canine species is one of the animals which, over history, has shared its life more closely with man, since the domestication of the dog took place 100000 years ago (Vilà et al. 1997). Over the centuries, the influence of man in the selection and breeding of this species has been very profound (changes of size, changes of coat colour, changes of character and behaviour, according to their function, etc.). This selective action has contributed towards determining different populations, depending on their kinds of functions (hunting dogs, guard dogs, livestock dogs, racing dogs, etc.)

The aim of this study was to determine whether the grouping of local Spanish dog breeds, obtained by discrimination of morphometric traits, matches up or differs from the classification based on the aptitude for which these breeds were bred, following the criteria and approach of the $\mathrm{FCl}$ and the RSCE. 


\section{Material and methods}

\section{Data collection}

A total of 1365 adult (over two year-old) dogs were studied, 709 females (F) and 656 males (M), belonging to sixteen different breeds (Table 1), two of which have not yet officially been recognized by the RSCE: the »Orito« and »Paternino« hound.

The dogs belong to group 1 (Sheepdogs and Cattle dogs), 2 (guarding and defending properties), 3 (Terriers), 5 (Spitz and primitive types), 6 (Scenthounds), 7 (Pointing dogs), 8 (Retrievers - Flushing dogs - Water dogs) and 10 (Sighthounds), according to the $\mathrm{FCl}$ classification. Following the criteria and approach developed through our research, the Orito and Paternino breeds were included within the fifth $\mathrm{FCl}$ group. The animals were identified individually, in order to avoid measuring any dogs twice, and were chosen randomly, to avoid animals from the same family. The animals subject to this study came from the main location area where each population occurs. These animals were also entered in the Spanish Stud Book (LOE according to its initials in Spanish) or in the Registry of Dog Breeds (or the RRC, according to its initials in Spanish). These are the two official record systems set up in Spain by the RSCE. Only those dogs entered in the LOE or RRC were chosen to be studied, since there is a proper record available of their ancestors over various generations. By contrast, the animals belonging to Orito and Paternino populations were chosen to be studied according to the criteria of the breeders who are members of the Breeders Associations in charge of the initial development of the breed, since there is still no official studbook for these two breeds.

\section{Morphometric variables}

A total of 15 body measures were taken following the procedure previously described by González et al. (2011). In Figure 1, the morphometric variables and their reference points are shown. These traits were studied by measuring bony prominences which are not affected by the conformation of the animal. The measurements (Table 2) were obtained by using a measuring stick, a caliper and a tape measure.

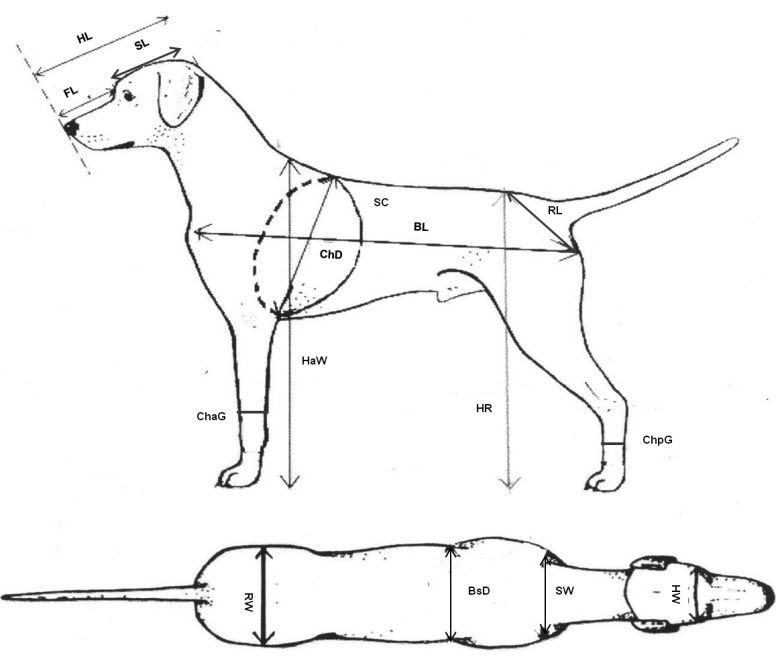

Figure 1

Body measurements used for morphologic characterization of dogs Abbreviations of traits: see Table 1 
Table 1

Classification of local Spanish dog breeds by group of $\mathrm{FCl}$, number of animals sampled and information for each dog breed and sex

\begin{tabular}{|c|c|c|c|c|c|c|c|}
\hline \multirow[t]{2}{*}{$\mathrm{FCl}$ group } & \multirow[t]{2}{*}{ Breeds } & \multirow[t]{2}{*}{$\begin{array}{l}\text { Abbreviation } \\
\text { of breeds }\end{array}$} & \multicolumn{2}{|c|}{$\begin{array}{l}\text { Animal } \\
\text { sampled }\end{array}$} & \multirow[t]{2}{*}{$\begin{array}{c}\text { Number of } \\
\text { Reference (FCl/RSCE) }\end{array}$} & \multicolumn{2}{|c|}{$\begin{array}{c}\text { Height at } \\
\text { withers, } \mathrm{cm}^{\mathrm{a}}\end{array}$} \\
\hline & & & Females & Males & & Females & Males \\
\hline Sheepdogs and Cattle Dogs & Mallorcan Shepherd Dog or Ca de Bestiar & CAD & 32 & 31 & $321 / 30.08 .2002 / E$ & $62-68$ & $66-73$ \\
\hline \multirow[t]{2}{*}{ (except Swiss Cattle Dogs) (1st) } & Catalonian Shepherd Dog or Gos d'Atura & GOS & 31 & 18 & 87 / 13.09. 2004 / E & $45-53$ & $47-55$ \\
\hline & Majorero & MAJ & 31 & 33 & 402 & $\geq 54$ & $\geq 56$ \\
\hline Pinscher and Schnauzer - Molossoid & Pyrenean Mastiff & MAP & 35 & 37 & 92 / 30.08. 2002 / E & $\geq 75$ & $\geq 81$ \\
\hline Breeds - Swiss Mountain and Cattle & Spanish Mastiff & MAE & 34 & 40 & $91 / 30.08 .2002$ / E & $\geq 75$ & $\geq 80$ \\
\hline \multirow[t]{2}{*}{ Dogs (2nd) } & Mallorcan Dogue or Ca de Bou & CAD & 16 & 21 & $249 / 11.12 .1996 / \mathrm{E}$ & $52-55$ & $55-58$ \\
\hline & Canary Dogue & PRC & 54 & 36 & $346 / 15.06 .2001 / E$ & $56-62$ & $60-66$ \\
\hline Terriers (3rd) & Ratonero Bodeguero Andaluz & RAT & 95 & 76 & 404 & $35-41$ & $37-43$ \\
\hline \multirow[t]{2}{*}{ Spitz and Primitive types (5th) } & Canarian Hound & POC & 40 & 24 & $329 / 03.11 .1999 / \mathrm{E}$ & $53-60$ & $55-64$ \\
\hline & Ibizan Hound or Ca Eivissenc & POI & 36 & 31 & $89 / 04.02 .2000 / E$ & $60-67$ & $66-72$ \\
\hline Scenthounds and Related Breeds (6th) & Spanish hound & $\mathrm{SAB}$ & 31 & 29 & 204 / 24. 07. 2000 / E & $48-53$ & $52-57$ \\
\hline Pointing Dogs (7th) & Perdiguero of Burgos & PER & 23 & 30 & 90 / 09. 11. 1998 / E & $59-64$ & $62-67$ \\
\hline Retrievers - Flushing Dogs - Water & Spanish Water Dog & PEA & 70 & 88 & 336 / 03. 09. 1999 / E & $40-46$ & $44-50$ \\
\hline \multicolumn{8}{|l|}{ Dogs (8th) } \\
\hline Sighthounds (10th) & Spanish Sighthound & GA & 42 & 43 & 285 / 03. 06. 1998 / E & $60-68$ & $62-70$ \\
\hline \multirow[t]{2}{*}{ No officially recognized dog breeds } & Orito Hound & PO & 75 & 46 & & & \\
\hline & Paternino Hound & PAT & 74 & 72 & & & \\
\hline
\end{tabular}

Range of height at withers of breed standard 
Table 2

Body measurements

\begin{tabular}{|c|c|c|}
\hline Trait & & Description \\
\hline \multicolumn{3}{|l|}{ Distance, $\mathrm{cm}$} \\
\hline Head lenght & $\mathrm{HL}$ & $\begin{array}{l}\text { distance from the nape to the alveolar edge of the incisors I of } \\
\text { the upper jaw bone }\end{array}$ \\
\hline Height at withers & HaW & $\begin{array}{l}\text { distance from the highest point of the processus spinalis of the } \\
\text { vertebra thoracica to the floor }\end{array}$ \\
\hline Body length & $\mathrm{BL}$ & $\begin{array}{l}\text { distance from the most cranial point of the sternum to the most } \\
\text { caudal point of the pin bone }\end{array}$ \\
\hline Rump length & $\mathrm{RL}$ & distance from hips (Tuber coxae) to pins (Tuber ischii), \\
\hline Height at rump & $\mathrm{HR}$ & distance from the rump (ilium) to the floor \\
\hline Skull length & SL & distance from the nape to the occipital crest \\
\hline Face length & $\mathrm{FL}$ & distance from the occipital crest to the lower lip \\
\hline \multicolumn{3}{|l|}{ Width measurements, $\mathrm{cm}$} \\
\hline Head width & HW & distance between two zygomatic arches \\
\hline Rump width & RW & distance from the left to the right point of hip \\
\hline Shoulder width & SW & $\begin{array}{l}\text { distance from left to right upper arm (pars cranialis of the } \\
\text { tuberculum majus humeri) }\end{array}$ \\
\hline \multicolumn{3}{|l|}{ Perimeters, cm } \\
\hline Chest depth & $\mathrm{ChD}$ & distance from the left to the right point of the back \\
\hline Back-sternal diameter & BsD & distance from dorsum to sternum \\
\hline Shin circumference & SC & measured in place of the saddle girth \\
\hline Chest anterior girth & ChaG & smallest circumference of cannon bone of the forelimb \\
\hline Chest posterior girth & ChpG & smallest circumference of can bone of the hindlimb \\
\hline
\end{tabular}

Using these body measurements, a total of 10 body indices were estimated (Table 3).

Table 3

Estimated body indices

\begin{tabular}{lll}
\hline Index & & \\
\hline Body index & $\mathrm{BI}$ & $\mathrm{BL} \times 100 / \mathrm{SC}$ \\
Proportionality index & $\mathrm{Prl}$ & $\mathrm{HaW} \times 100 / \mathrm{BL}$ \\
Thoracic index & $\mathrm{TI}$ & $\mathrm{ChD} \times 100 / \mathrm{BsD}$ \\
Dactyl-thoracic index & $\mathrm{DTI}$ & $\mathrm{ChaG} \times 100 / \mathrm{SC}$ \\
Dactyl-costal index & $\mathrm{DCl}$ & $\mathrm{ChaG} \times 100 / \mathrm{RW}$ \\
Relative thickness of the cane bone index & $\mathrm{RTCl}$ & $\mathrm{ChaG} \times 100 / \mathrm{HaW}$ \\
Pelvic index & $\mathrm{PI}$ & $\mathrm{RW} \times 100 / \mathrm{RL}$ \\
Longitudinal pelvic index & $\mathrm{LPI}$ & $\mathrm{RL} \times 100 / \mathrm{HaW}$ \\
Transversal pelvic index & $\mathrm{TPI}$ & $\mathrm{RW} \times 100 / \mathrm{HaW}$ \\
Relative proportionality of the thorax index & $\mathrm{RPTI}$ & $\mathrm{BsD} \times 100 / \mathrm{HaW}$ \\
\hline
\end{tabular}




\section{Statistical analysis}

Following the main goal of this study, the first step was to describe each breed morphometrically from the resulting information from the main descriptive statistics (mean and corresponding standard error) of those fifteen morphometric variables and ten indices. An ANOVA and Tukey's test were carried out to analyse the effect of breed and sex.

Through the discriminant analysis, we obtained percentages of the correct attachment of animals to each breed, to which they had previously been assigned by classification matrices. We also obtained the Mahalanobis distances among the different breeds, which were represented using a cluster tree.

The second step was to group all the animals belonging to the same breed according to the classification established by the $\mathrm{FCl}$ in order to obtain the correlations between the shape and functional activities of these animals. As we had done in the case of breed, the descriptive statistic of each $\mathrm{FCl}$ group by sex and the effect of this factor by an ANOVA and Tukey's test were obtained. The percentages of correct assignment of individuals to each $\mathrm{FCl}$ groups were estimated too. Canonical procedures clarified the classifying breeds into groups and their results were expressed through the graphical representation of canonical coefficients. Statistical analysis was carried out using the software Statistica for Windows 8.0 (Statsoft, Inc., Tulsa, OK, USA).

\section{Results}

\section{Morphometric characterization and differentiation of breeds}

Table S1 shows the mean values of biometric measurements. The lowest mean values of height at withers were obtained by Ratonero Bodeguero Andaluz and the highest by both Mastiffs. Regarding length measures, the dog breed which showed the smallest format, both in head and body, was again the Ratonero Bodeguero Andaluz, and the Spanish Mastiff was also the dog breed which showed the largest format. Both Mastiff breeds also showed the most extreme results in relation to width, and the Ratonero Bodeguero Andaluz showed the lowest average for Shin circumference, with the Spanish Mastiff showing the highest average value. In contrast, two breeds which showed very different average HaW values (Catalonian Shepherd and Canary Dogue dog breeds), also showed a similar value for the relationship between the $\mathrm{HaW}$ and the $\mathrm{HL}$. The general conformation is shown by different indices. Spanish dog breeds also showed a clear differentiation in body indices (Table S2). Through the body index, our results showed that the Ibizan Hound was the breed with the greatest body size and the Canary Dogue the smallest, with a difference among HaW and $\mathrm{SC}$ of 4 and $13 \mathrm{~cm}$, respectively. The Prl index shows the difference between HaW and BL, and those animals with a similar value of both measures had a square format, as occurred in those breeds that showed a value in this index closer to 100. In contrast, breeds with rectangular format are obtained for those animals with a BL higher than HaW. This fact was more marked in the Spanish Sighthound and Spanish Mastiff than in the other breeds, where the difference between both measurements was over $10 \mathrm{~cm}$. Both indices are related because those breeds with high values in $\mathrm{BI}$ had also high value in Prl, as occurred in the Ibizan Hound. Bone development is shown by the dactyl-thoracic, dactyl-costal and relative thickness of the cannon bone indices. The values obtained showed that the Paternino Hound 
and Spanish Sighthound breeds had lower bone development - the former breed had with lowest value in $\mathrm{DCl}$ and the latter in DTI and RTCI. In contrast, the breeds with the greatest bone development were the Spanish Water Dog for DTI, Spanish Hound for DCI and Canary Dogue for RTCI. In the same way, rump conformation is shown by both the longitudinal pelvic and transversal pelvic indices, and the Spanish Hound was the breed with the highest value in LPI, and Spanish Water Dog and Paternino Hound the breed with the highest values in TPI. Thus, there is a great development of the posterior third in those animals. In contrast, the Spanish Sighthound and the Ibizan and Canarian Hound were those with the smallest values in both pelvic indices. The thorax depth relative to the height at withers was evidenced by the relative proportionality of the thorax index (the higher values are linked to greater depth), where the highest value was obtained in the Spanish Sighthound and the lowest in the Ibizan Hound.

The ANOVA test showed a great differentiation between breeds in both sexes for biometric traits and body indices (Tables S1 and S2). However, the effect of sex showed the highest differences for biometric traits in the Spanish Sighthound, Spanish Water Dog, Canary Dogue and Pyrenean Mastiff breeds, with a difference in the mean value of each measure of at least of $1 \mathrm{~cm}$, which in some cases reached $4 \mathrm{~cm}$. In contrast, the smallest differences were shown in the Orito Hound, where the differences in biometric measures were below $1 \mathrm{~cm}$ in most of them. In the case of body indices, the differences between sexes were only statistically significant $(P<0.05)$ for Prl and DTI in Ca de Bestiar, for DTI in the Pyrenean Mastiff and Orito Hound, and for BI in the Spanish Water Dog.

\section{Morphometric characterization and differentiation relative to $\mathrm{FCl}$ groups}

In each $\mathrm{FCl}$ group breeds can be found with different body conformation, although they have similar aptitude. For example, in the first group, which includes Ca de Bestiar, Gos d'Atura and Majorero, the highest mean values of all biometric traits in both sexes were found in $\mathrm{Ca}$ de Bestiar and the lowest in Gos d'Atura, with Ca de Bestiar also having the biggest head in relation to height $(\mathrm{HL} / \mathrm{HaW})$. In the case of the second group, which includes both Mastiffs, Ca de Bou and Canary Dogue, in females and males the largest format and the biggest head were found in the Spanish Mastiff, and the smallest in Ca de Bou. The last group which includes different breeds is the fifth, covering the Hounds, in which the lbizan Hound showed the highest values in all biometric traits and in its relationship among $\mathrm{HaW}$ and $\mathrm{HL}$; the Orito Hound was the lowest in these measurements and the Paternino in the case of the head size in its relationship with $\mathrm{HaW}$.

Average values with standard errors of all animals classified according to the same function are shown by sex in Table 4.

As expected, the smallest mean values of biometric traits were found in the third group of $\mathrm{FCl}$ and the highest in the second group, with the exception of the FL measurement, which was bigger in the tenth group than second one. However, the head was found to be the smallest in relation to $\mathrm{HaW}$ in the sixth $\mathrm{FCl}$ group and bigger in the tenth.

Table 5 shows the mean values and effect of sex in body indices of $\mathrm{FCl}$ groups. 
Table 4

Descriptive statistics (mean and standard error), analysis of variance and differentiation through Tukey's test for females for 709 females and 656 males of $8 \mathrm{FCl}$ groups by 15 morphometric variables

\begin{tabular}{|c|c|c|c|c|c|c|c|c|}
\hline $\mathrm{FCl}$ group & & $\mathrm{HaW}, \mathrm{cm}$ & $\mathrm{HR}, \mathrm{cm}$ & $\mathrm{BL}, \mathrm{cm}$ & $\mathrm{BsD}, \mathrm{cm}$ & $\mathrm{ChD}, \mathrm{cm}$ & $\mathrm{HL}, \mathrm{cm}$ & $\mathrm{SL}, \mathrm{cm}$ \\
\hline \multirow[t]{3}{*}{$1 s t$} & Females & $57.14 \pm 0.61^{d}$ & $56.80 \pm 0.62^{d}$ & $57.91 \pm 0.62^{d}$ & $22.44 \pm 0.31^{c}$ & $15.07 \pm 0.24^{\mathrm{cd}}$ & $21.43 \pm 0.19^{c}$ & $12.87 \pm 0.13^{c}$ \\
\hline & Males & $61.45 \pm 0.73^{\mathrm{a}}$ & $60.88 \pm 0.72^{\mathrm{d}}$ & $61.11 \pm 0.72^{d}$ & $24.66 \pm 0.37^{c}$ & $15.89 \pm 0.25^{d}$ & $22.60 \pm 0.24^{c}$ & $14.09 \pm 0.15^{c}$ \\
\hline & $P$-value ${ }^{1}$ & $<0.001$ & $<0.001$ & $<0.001$ & $<0.001$ & 0.02 & $<0.001$ & $<0.001$ \\
\hline \multirow[t]{3}{*}{ 2nd } & Females & $65.71 \pm 0.70^{f}$ & $66.36 \pm 0.68^{f}$ & $70.62 \pm 0.81^{f}$ & $28.52 \pm 0.36^{\mathrm{e}}$ & $19.55 \pm 0.25^{c}$ & $24.44 \pm 0.24^{\mathrm{e}}$ & $15.13 \pm 0.12^{d}$ \\
\hline & Males & $71.22 \pm 0.82^{c}$ & $71.55 \pm 0.84^{\mathrm{e}}$ & $75.62 \pm 0.94^{f}$ & $30.58 \pm 0.38^{e}$ & $21.55 \pm 0.61^{f}$ & $26.15 \pm 0.28^{e}$ & $16.36 \pm 0.15^{d}$ \\
\hline & $P$-value ${ }^{1}$ & $<0.001$ & $<0.001$ & $<0.001$ & $<0.001$ & $<0.01$ & $<0.001$ & $<0.001$ \\
\hline \multirow[t]{3}{*}{$3 r d$} & Females & $38.11 \pm 0.20^{\mathrm{a}}$ & $37.31 \pm 0.23^{a}$ & $38.71 \pm 0.34^{a}$ & $15.00 \pm 0.18^{a}$ & $10.51 \pm 0.18^{a}$ & $15.21 \pm 0.09^{a}$ & $9.22 \pm 0.09^{a}$ \\
\hline & Males & $40.65 \pm 0.27^{c}$ & $39.53 \pm 0.31^{\mathrm{a}}$ & $39.93 \pm 0.40^{\mathrm{a}}$ & $15.46 \pm 0.26^{\mathrm{a}}$ & $10.96 \pm 0.21^{\mathrm{a}}$ & $15.78 \pm 0.19^{a}$ & $9.64 \pm 0.09^{\mathrm{a}}$ \\
\hline & $P$-value ${ }^{1}$ & $<0.001$ & $<0.001$ & 0.02 & 0.13 & 0.11 & $<0.01$ & $<0.01$ \\
\hline \multirow[t]{3}{*}{5 th } & Females & $52.94 \pm 0.63^{c}$ & $52.47 \pm 0.61^{c}$ & $53.15 \pm 0.57^{c}$ & $19.72 \pm 0.21^{b}$ & $12.62 \pm 0.14^{b}$ & $19.31 \pm 0.18^{b}$ & $10.24 \pm 0.13^{b}$ \\
\hline & Males & $55.89 \pm 0.74^{d}$ & $55.10 \pm 0.72^{c}$ & $56.17 \pm 0.70^{c}$ & $20.98 \pm 0.26^{b}$ & $13.20 \pm 0.15^{b}$ & $20.69 \pm 0.24^{b}$ & $11.01 \pm 0.15^{b}$ \\
\hline & $P$-value ${ }^{1}$ & $<0.01$ & $<0.01$ & $<0.001$ & $<0.001$ & $<0.01$ & $<0.001$ & $<0.001$ \\
\hline \multirow[t]{3}{*}{ 6th } & Females & $48.94 \pm 0.48^{b c}$ & $49.23 \pm 0.56^{c}$ & $60.43 \pm 0.57^{\mathrm{de}}$ & $22.90 \pm 0.41^{c}$ & $15.24 \pm 0.28^{c d}$ & $21.83 \pm 0.37^{c d}$ & $12.61 \pm 0.25^{c}$ \\
\hline & Males & $52.24 \pm 0.49^{d e}$ & $52.57 \pm 0.54^{c}$ & $63.40 \pm 0.76^{\mathrm{de}}$ & $24.22 \pm 0.38^{c}$ & $16.35 \pm 0.30^{d}$ & $23.86 \pm 0.20^{\mathrm{cd}}$ & $13.94 \pm 0.23^{c}$ \\
\hline & $P$-value ${ }^{1}$ & $<0.001$ & $<0.001$ & $<0.01$ & 0.02 & $<0.01$ & $<0.001$ & $<0.001$ \\
\hline \multirow[t]{3}{*}{ 7th } & Females & $60.61 \pm 0.61^{\text {de }}$ & $58.79 \pm 0.78^{\text {de }}$ & $60.43 \pm 0.64^{\mathrm{de}}$ & $25.63 \pm 0.75^{d}$ & $17.26 \pm 0.45^{d}$ & $23.28 \pm 0.25^{\mathrm{de}}$ & $13.13 \pm 0.19^{c}$ \\
\hline & Males & $64.82 \pm 0.36^{\mathrm{ef}}$ & $62.49 \pm 0.46^{d}$ & $64.59 \pm 0.58^{\mathrm{de}}$ & $27.08 \pm 0.41^{d}$ & $17.27 \pm 0.33^{e}$ & $24.93 \pm 0.20^{d e}$ & $14.58 \pm 0.20^{c}$ \\
\hline & $P$-value ${ }^{1}$ & $<0.001$ & $<0.001$ & $<0.001$ & 0.08 & 0.99 & $<0.001$ & $<0.001$ \\
\hline \multirow[t]{3}{*}{ 8th } & Females & $44.23 \pm 0.29^{b}$ & $43.76 \pm 0.3^{b}$ & $46.90 \pm 0.55^{b}$ & $19.45 \pm 0.24^{b}$ & $14.31 \pm 0.21^{\mathrm{cd}}$ & $18.84 \pm 0.20^{\mathrm{b}}$ & $10.31 \pm 0.12^{b}$ \\
\hline & Males & $47.64 \pm 0.22^{f}$ & $46.89 \pm 0.26^{b}$ & $50.59 \pm 0.42^{\mathrm{b}}$ & $20.94 \pm 0.16^{b}$ & $15.30 \pm 0.16^{c d}$ & $19.96 \pm 0.16^{\mathrm{b}}$ & $11.18 \pm 0.10^{b}$ \\
\hline & $P$-value ${ }^{1}$ & $<0.001$ & $<0.001$ & $<0.001$ & $<0.001$ & $<0.001$ & $<0.001$ & $<0.001$ \\
\hline \multirow[t]{3}{*}{ 10th } & Females & $64.98 \pm 0.33^{e f}$ & $64.19 \pm 0.34^{\mathrm{e}}$ & $65.02 \pm 0.55^{\mathrm{e}}$ & $23.71 \pm 0.24^{\mathrm{cd}}$ & $13.24 \pm 0.26^{\mathrm{bc}}$ & $22.31 \pm 0.16^{\mathrm{cd}}$ & $12.81 \pm 0.14^{c}$ \\
\hline & Males & $68.40 \pm 0.34^{\mathrm{b}}$ & $66.57 \pm 0.39^{e}$ & $67.83 \pm 0.53^{\mathrm{e}}$ & $25.53 \pm 0.23^{c d}$ & $14.09 \pm 0.25^{\mathrm{bc}}$ & $23.58 \pm 0.15^{c d}$ & $13.59 \pm 0.15^{c}$ \\
\hline & $P$-value ${ }^{1}$ & $<0.001$ & $<0.001$ & $<0.001$ & $<0.001$ & 0.02 & $<0.001$ & $<0.001$ \\
\hline \multirow[t]{3}{*}{$P$-value } & Females $^{2}$ & $<0.001$ & $<0.001$ & $<0.001$ & $<0.001$ & $<0.001$ & $<0.001$ & $<0.001$ \\
\hline & Males $^{2}$ & $<0.001$ & $<0.001$ & $<0.001$ & $<0.001$ & $<0.001$ & $<0.001$ & $<0.001$ \\
\hline & $P$-value ${ }^{1}$ & $<0.001$ & $<0.001$ & $<0.001$ & $<0.001$ & $<0.001$ & $<0.001$ & $<0.001$ \\
\hline
\end{tabular}

Abbreviation of traits: see Table $2,{ }^{a}, b, c, d, e, f$ Means having different superscript letters within columns differ $(P \leq 0.001), \quad{ }^{1}$ ANOVA test between females and males, ${ }^{2}$ ANOVA test between breeds for females and males 
Table 4

Descriptive statistics (mean and standard error), analysis of variance and differentiation through Tukey's test for females for 709 females and 656 males of $8 \mathrm{FCl}$ groups by 15 morphometric variables - continuation

\begin{tabular}{|c|c|c|c|c|c|c|c|c|c|}
\hline $\mathrm{FCl}$ group & & $\mathrm{FL}, \mathrm{cm}$ & $\mathrm{HW}, \mathrm{cm}$ & $\mathrm{SW}, \mathrm{cm}$ & $\mathrm{RW}, \mathrm{cm}$ & $\mathrm{RL}, \mathrm{cm}$ & $\mathrm{SC}, \mathrm{cm}$ & ChaG, cm & ChpG, cm \\
\hline \multirow[t]{3}{*}{$1 s t$} & Females & $8.55 \pm 0.14^{\text {bc }}$ & $11.21 \pm 0.11^{d}$ & $12.54 \pm 0.20^{c}$ & $9.35 \pm 0.16^{b}$ & $15.73 \pm 0.22^{d}$ & $70.03 \pm 0.92^{d}$ & $11.05 \pm 0.14^{d}$ & $10.43 \pm 0.10^{d}$ \\
\hline & Males & $9.08 \pm 0.10^{b c}$ & $12.29 \pm 0.14^{\mathrm{e}}$ & $13.40 \pm 0.26^{\text {cde }}$ & $9.52 \pm 0.18^{c}$ & $16.73 \pm 0.26^{d}$ & $75.41 \pm 0.95^{\mathrm{de}}$ & $12.18 \pm 0.14^{d}$ & $11.52 \pm 0.15^{\mathrm{de}}$ \\
\hline & $P$-value ${ }^{1}$ & $<0.01$ & $<0.001$ & $<0.01$ & 0.46 & $<0.01$ & $<0.001$ & $<0.001$ & $<0.001$ \\
\hline \multirow[t]{3}{*}{ 2nd } & Females & $9.19 \pm 0.16^{d}$ & $13.58 \pm 0.09^{e}$ & $16.76 \pm 0.22^{\mathrm{e}}$ & $11.67 \pm 0.22^{c}$ & $18.64 \pm 0.23^{e}$ & $86.78 \pm 0.85^{e}$ & $14.26 \pm 0.12^{f}$ & $13.38 \pm 0.14^{e}$ \\
\hline & Males & $9.72 \pm 0.17^{d}$ & $14.60 \pm 0.11^{f}$ & $18.21 \pm 0.25^{f}$ & $12.57 \pm 0.23^{d}$ & $20.15 \pm 0.29^{e}$ & $93.24 \pm 1.05^{f}$ & $15.62 \pm 0.16^{f}$ & $14.70 \pm 0.18^{f}$ \\
\hline & $P$-value ${ }^{1}$ & 0.02 & $<0.001$ & $<0.001$ & $<0.01$ & $<0.001$ & $<0.001$ & $<0.001$ & $<0.001$ \\
\hline \multirow[t]{3}{*}{$3 r d$} & Females & $5.78 \pm 0.07^{\mathrm{a}}$ & $8.50 \pm 0.08^{\mathrm{a}}$ & $8.29 \pm 0.13^{\mathrm{a}}$ & $6.35 \pm 0.13^{\mathrm{a}}$ & $10.61 \pm 0.15^{\mathrm{a}}$ & $47.22 \pm 0.45^{\mathrm{a}}$ & $7.33 \pm 0.06^{\mathrm{a}}$ & $6.77 \pm 0.06^{a}$ \\
\hline & Males & $6.10 \pm 0.08^{\mathrm{a}}$ & $9.18 \pm 0.07^{\mathrm{a}}$ & $8.71 \pm 0.14^{\mathrm{a}}$ & $6.51 \pm 0.14^{\mathrm{a}}$ & $11.34 \pm 0.18^{\mathrm{a}}$ & $49.13 \pm 0.53^{\mathrm{a}}$ & $7.89 \pm 0.08^{\mathrm{a}}$ & $7.11 \pm 0.07^{\mathrm{a}}$ \\
\hline & $P$-value ${ }^{1}$ & $<0.01$ & $<0.001$ & 0.03 & 0.40 & $<0.01$ & $<0.01$ & $<0.001$ & $<0.001$ \\
\hline \multirow[t]{3}{*}{5 th } & Females & $9.35 \pm 0.07^{d}$ & $9.43 \pm 0.06^{b}$ & $11.28 \pm 0.15^{b}$ & $9.06 \pm 0.13^{b}$ & $13.92 \pm 0.16^{c}$ & $58.48 \pm 0.47^{b}$ & $9.36 \pm 0.07^{b}$ & $8.71 \pm 0.07^{b c}$ \\
\hline & Males & $9.82 \pm 0.09^{\mathrm{de}}$ & $10.18 \pm 0.09^{b}$ & $12.36 \pm 0.20^{b}$ & $10.07 \pm 0.67^{\mathrm{bc}}$ & $15.02 \pm 0.19^{c}$ & $61.71 \pm 0.56^{b}$ & $10.10 \pm 0.08^{b}$ & $9.94 \pm 0.50^{\mathrm{b}}$ \\
\hline & $P$-value ${ }^{1}$ & $<0.001$ & $<0.001$ & $<0.001$ & 0.09 & $<0.001$ & $<0.001$ & $<0.001$ & $<0.01$ \\
\hline \multirow[t]{3}{*}{ 6th } & Females & $9.19 \pm 0.15^{\mathrm{cd}}$ & $10.41 \pm 0.1^{c}$ & $12.97 \pm 0.38^{\mathrm{cd}}$ & $7.94 \pm 0.38^{\mathrm{ab}}$ & $14.52 \pm 0.25^{c d}$ & $64.90 \pm 0.83^{c}$ & $11.18 \pm 0.26^{\mathrm{cd}}$ & $9.77 \pm 0.14^{\mathrm{bcd}}$ \\
\hline & Males & $9.59 \pm 0.14^{\text {cde }}$ & $11.39 \pm 0.16^{\mathrm{cd}}$ & $14.01 \pm 0.32^{\mathrm{de}}$ & $7.89 \pm 0.32^{\mathrm{b}}$ & $15.88 \pm 0.26^{c d}$ & $69.62 \pm 0.95^{c}$ & $11.46 \pm 0.1^{\mathrm{de}}$ & $10.58 \pm 0.11^{\mathrm{cd}}$ \\
\hline & $P$-value ${ }^{1}$ & $<0.001$ & $<0.001$ & 0.04 & 0.92 & $<0.001$ & $<0.001$ & 0.38 & $<0.001$ \\
\hline \multirow[t]{3}{*}{7 th } & Females & $10.07 \pm 0.19^{e}$ & $10.82 \pm 0.12^{\mathrm{cd}}$ & $13.97 \pm 0.55^{b}$ & $8.84 \pm 0.38^{\mathrm{ab}}$ & $15.35 \pm 0.28^{d}$ & $74.42 \pm 1.03^{d}$ & $11.93 \pm 0.12 \mathrm{e}$ & $10.95 \pm 0.14^{c d}$ \\
\hline & Males & $10.80 \pm 0.40^{\text {de }}$ & $12.09 \pm 0.17^{\mathrm{de}}$ & $15.61 \pm 0.30^{\mathrm{e}}$ & $9.18 \pm 0.32^{\mathrm{bc}}$ & $16.78 \pm 0.24^{d}$ & $79.54 \pm 0.81^{\mathrm{e}}$ & $13.14 \pm 0.15^{\mathrm{e}}$ & $11.81 \pm 0.15^{\mathrm{e}}$ \\
\hline & $P$-value ${ }^{1}$ & 0.13 & $<0.001$ & $<0.01$ & 0.50 & $<0.001$ & $<0.001$ & $<0.001$ & $<0.001$ \\
\hline \multirow[t]{3}{*}{ 8th } & Females & $8.16 \pm 0.15^{b}$ & $8.83 \pm 0.12^{\mathrm{a}}$ & $12.34 \pm 0.27^{\mathrm{bc}}$ & $9.53 \pm 0.45^{b}$ & $12.88 \pm 0.19^{b}$ & $58.96 \pm 0.55^{b}$ & $10.23 \pm 0.13^{c}$ & $9.56 \pm 0.13^{\mathrm{bcd}}$ \\
\hline & Males & $8.57 \pm 0.12^{\mathrm{b}}$ & $9.49 \pm 0.11^{\mathrm{a}}$ & $13.24 \pm 0.28^{\mathrm{cd}}$ & $9.61 \pm 0.37^{c}$ & $13.82 \pm 0.20^{b}$ & $61.61 \pm 0.51^{\mathrm{b}}$ & $10.93 \pm 0.10^{c}$ & $10.10 \pm 0.10^{c}$ \\
\hline & $P$-value ${ }^{1}$ & 0.03 & $<0.001$ & 0.02 & 0.89 & $<0.01$ & $<0.001$ & $<0.001$ & $<0.001$ \\
\hline \multirow[t]{3}{*}{ 10th } & Females & $9.89 \pm 0.14^{\mathrm{e}}$ & $10.00 \pm 0.09^{b}$ & $11.38 \pm 0.16^{b}$ & $8.46 \pm 0.22^{\mathrm{ab}}$ & $15.23 \pm 0.17^{d}$ & $66.93 \pm 0.45^{c}$ & $9.19 \pm 0.14^{b}$ & $8.69 \pm 0.13^{\mathrm{ab}}$ \\
\hline & Males & $10.57 \pm 0.14^{\mathrm{e}}$ & $10.55 \pm 0.11^{c}$ & $11.97 \pm 0.13^{b c}$ & $9.16 \pm 0.22^{\mathrm{bc}}$ & $16.59 \pm 0.21^{d}$ & $70.21 \pm 0.57^{c d}$ & $9.75 \pm 0.11^{b}$ & $9.17 \pm 0.09^{b}$ \\
\hline & $P$-value ${ }^{1}$ & $<0.001$ & $<0.001$ & $<0.01$ & 0.03 & $<0.001$ & $<0.001$ & $<0.01$ & $<0.01$ \\
\hline \multirow[t]{3}{*}{$P$-value } & Females $^{2}$ & $<0.001$ & $<0.001$ & $<0.001$ & $<0.001$ & $<0.001$ & $<0.001$ & $<0.001$ & $<0.001$ \\
\hline & Males $^{2}$ & $<0.001$ & $<0.001$ & $<0.001$ & $<0.001$ & $<0.001$ & $<0.001$ & $<0.001$ & $<0.001$ \\
\hline & $P$-value ${ }^{1}$ & $<0.001$ & $<0.001$ & $<0.001$ & $<0.001$ & $<0.001$ & $<0.001$ & $<0.001$ & $<0.001$ \\
\hline
\end{tabular}

Abbreviation of traits: see Table $2, \quad a, b, c, d, e, f$ Means having different superscript letters within columns differ $(P \leq 0.001), \quad{ }^{1}$ ANOVA test between females and males, ${ }^{2}$ ANOVA test between breeds for females and males 
Table 5

Descriptive statistics (mean and standard error), analysis of variance and differentiation through Tukey's test for females for 709 females and 656 males of $8 \mathrm{FCl}$ groups by 10 functional indices

\begin{tabular}{|c|c|c|c|c|c|c|c|c|c|c|c|}
\hline $\mathrm{FCl}$ group & & $\mathrm{BI}$ & $\mathrm{Prl}$ & $\mathrm{TI}$ & DTI & $\mathrm{DCl}$ & $\mathrm{RTCl}$ & $\mathrm{PI}$ & LPI & TPI & RPTI \\
\hline \multirow[t]{3}{*}{$1 s t$} & Females & $83.26 \pm 0.84^{\mathrm{a}}$ & $98.85 \pm 0.79^{\mathrm{a}}$ & $67.47 \pm 1.06^{\mathrm{ab}}$ & $15.86 \pm 0.17^{a}$ & $120.62 \pm 2.7^{\mathrm{ab}}$ & $19.37 \pm 0.22^{\mathrm{a}}$ & $59.81 \pm 1.59^{\mathrm{a}}$ & $27.56 \pm 0.35^{b c}$ & $16.41 \pm 0.46^{\mathrm{ab}}$ & $39.32 \pm 0.41^{c}$ \\
\hline & Males & $81.45 \pm 0.86^{\mathrm{a}}$ & $100.80 \pm 0.83^{\mathrm{a}}$ & $65.14 \pm 1.41^{\mathrm{a}}$ & $16.21 \pm 0.19^{a}$ & $130.71 \pm 2.80^{\mathrm{a}}$ & $19.88 \pm 0.24^{\mathrm{a}}$ & $57.33 \pm 3.59^{\mathrm{a}}$ & $27.24 \pm 0.37^{\mathrm{ab}}$ & $15.56 \pm 0.94^{\mathrm{ab}}$ & $40.24 \pm 0.42^{c}$ \\
\hline & $P$-value & 0.11 & 0.05 & 0.10 & 0.08 & $<0.01$ & 0.04 & 0.07 & 0.42 & 0.03 & 0.15 \\
\hline \multirow[t]{3}{*}{ 2nd } & Females & $81.56 \pm 0.69^{a}$ & $93.39 \pm 0.65^{b}$ & $69.13 \pm 0.87^{a}$ & $16.52 \pm 0.14^{\mathrm{bc}}$ & $126.62 \pm 2.27^{\mathrm{bc}}$ & $21.85 \pm 0.18^{b}$ & $63.36 \pm 1.31^{\mathrm{ab}}$ & $28.43 \pm 0.29^{\mathrm{a}}$ & $17.83 \pm 0.38^{b}$ & $43.34 \pm 0.34^{\mathrm{a}}$ \\
\hline & Males & $81.21 \pm 0.68^{a}$ & $94.44 \pm 0.65^{b}$ & $70.65 \pm 1.1^{b c}$ & $16.83 \pm 0.15^{a}$ & $128.01 \pm 2.22^{\mathrm{a}}$ & $22.07 \pm 0.19^{b}$ & $63.56 \pm 2.84^{b}$ & $28.44 \pm 0.29^{\mathrm{bcd}}$ & $17.72 \pm 0.74^{\mathrm{abc}}$ & $43.03 \pm 0.34^{b}$ \\
\hline & $P$-value & 0.69 & 0.12 & 0.37 & 0.05 & 0.61 & 0.32 & 0.92 & 0.98 & 0.78 & 0.33 \\
\hline \multirow[t]{3}{*}{$3 r d$} & Females & $82.43 \pm 0.83^{a}$ & $98.98 \pm 0.79^{b}$ & $70.42 \pm 1.05^{a}$ & $15.61 \pm 0.17^{a}$ & $119.44 \pm 2.73^{\mathrm{ab}}$ & $19.26 \pm 0.22^{\mathrm{a}}$ & $60.12 \pm 1.58^{a}$ & $27.85 \pm 0.35^{\mathrm{ac}}$ & $16.68 \pm 0.46^{\mathrm{ab}}$ & $39.35 \pm 0.40^{c}$ \\
\hline & Males & $81.66 \pm 0.89^{a}$ & $102.31 \pm 0.86^{b}$ & $72.06 \pm 1.46^{b c}$ & $16.12 \pm 0.19^{a}$ & $124.62 \pm 2.91^{\mathrm{a}}$ & $19.44 \pm 0.25^{\mathrm{a}}$ & $57.77 \pm 3.73^{\mathrm{a}}$ & $27.86 \pm 0.39^{a b c}$ & $16.04 \pm 0.97^{\mathrm{ab}}$ & $37.99 \pm 0.44^{\mathrm{a}}$ \\
\hline & $P$-value & 0.53 & 0.01 & 0.43 & 0.02 & 0.13 & 0.46 & 0.14 & 0.97 & 0.20 & 0.05 \\
\hline \multirow[t]{3}{*}{5 th } & Females & $90.86 \pm 0.54^{b}$ & $99.85 \pm 0.51^{\mathrm{a}}$ & $65.07 \pm 0.68^{b}$ & $16.12 \pm 0.11^{\mathrm{ab}}$ & $108.17 \pm 1.78^{d}$ & $18.01 \pm 0.14 \mathrm{e}$ & $66.53 \pm 1.02^{\mathrm{b}}$ & $26.53 \pm 0.23^{b}$ & $17.56 \pm 0.30^{\mathrm{ab}}$ & $37.55 \pm 0.26^{b}$ \\
\hline & Males & $90.85 \pm 0.59^{b}$ & $99.81 \pm 0.57^{a}$ & $64.02 \pm 0.97^{a}$ & $16.37 \pm 0.13^{a}$ & $109.66 \pm 1.93^{b}$ & $18.31 \pm 0.17 e$ & $68.36 \pm 2.47^{c}$ & $27.09 \pm 0.26^{a}$ & $18.40 \pm 0.65^{b c}$ & $37.82 \pm 0.2^{\mathrm{a}}$ \\
\hline & $P$-value & 0.99 & 0.96 & 0.41 & 0.21 & 0.59 & 0.28 & 0.66 & 0.14 & 0.43 & 0.53 \\
\hline \multirow[t]{3}{*}{ 6th } & Females & $93.41 \pm 1.46^{b c}$ & $81.13 \pm 1.38^{d}$ & $67.05 \pm 1.84^{\mathrm{ab}}$ & $17.25 \pm 0.29^{c d}$ & $148.53 \pm 4.79 \mathrm{e}$ & $22.91 \pm 0.39^{b c}$ & $55.22 \pm 2.76^{\mathrm{a}}$ & $29.75 \pm 0.61^{\mathrm{a}}$ & $16.26 \pm 0.80^{\mathrm{abc}}$ & $46.89 \pm 0.71^{d}$ \\
\hline & Males & $91.37 \pm 1.44^{b c}$ & $82.66 \pm 1.39^{c}$ & $67.85 \pm 2.37^{\mathrm{abc}}$ & $16.50 \pm 0.31^{\mathrm{a}}$ & $150.83 \pm 4.71^{c}$ & $22.02 \pm 0.41^{b c}$ & $49.87 \pm 6.04^{d}$ & $30.46 \pm 0.63^{d}$ & $15.16 \pm 1.58^{\mathrm{abc}}$ & $46.46 \pm 0.71^{d}$ \\
\hline & $P$-value & 0.23 & 0.28 & 0.70 & 0.11 & 0.80 & 0.25 & 0.13 & 0.40 & 0.28 & 0.72 \\
\hline \multirow[t]{3}{*}{7 th } & Females & $81.48 \pm 1.70^{\mathrm{a}}$ & $100.48 \pm 1.60^{\mathrm{ac}}$ & $67.81 \pm 2.14^{\mathrm{abc}}$ & $16.08 \pm 0.34^{\mathrm{abc}}$ & $139.76 \pm 5.56^{c} \mathrm{e}$ & $19.72 \pm 0.45^{\mathrm{a}}$ & $58.60 \pm 3.21^{\mathrm{ab}}$ & $25.35 \pm 0.71^{b d}$ & $14.60 \pm 0.93^{\mathrm{ac}}$ & $42.28 \pm 0.82^{\mathrm{a}}$ \\
\hline & Males & $81.43 \pm 1.42^{\mathrm{a}}$ & $100.52 \pm 1.36^{a}$ & $64.10 \pm 2.33^{\mathrm{abd}}$ & $16.56 \pm 0.31^{\mathrm{a}}$ & $147.62 \pm 4.63^{c}$ & $20.29 \pm 0.40^{\mathrm{ac}}$ & $54.74 \pm 5.94^{\mathrm{a}}$ & $25.90 \pm 0.61^{\mathrm{a} e}$ & $14.16 \pm 1.55^{\mathrm{ab}}$ & $41.78 \pm 0.70^{\mathrm{bc}}$ \\
\hline & $P$-value & 0.97 & 0.98 & 0.09 & 0.16 & 0.28 & 0.13 & 0.32 & 0.34 & 0.58 & 0.68 \\
\hline \multirow[t]{3}{*}{ 8th } & Females & $79.70 \pm 0.97^{a}$ & $95.00 \pm 0.92^{c d}$ & $73.84 \pm 1.22^{c}$ & $17.42 \pm 0.19^{d}$ & $121.12 \pm 3.19^{a b c}$ & $23.17 \pm 0.26^{c}$ & $73.24 \pm 1.84^{c}$ & $29.22 \pm 0.41^{\mathrm{a}}$ & $21.67 \pm 0.54^{d}$ & $44.00 \pm 0.47^{a}$ \\
\hline & Males & $82.63 \pm 0.83^{a}$ & $94.72 \pm 0.80^{\mathrm{b}}$ & $73.20 \pm 1.36^{c}$ & $17.84 \pm 0.18^{c}$ & $124.47 \pm 2.71^{a}$ & $22.98 \pm 0.24^{b}$ & $68.69 \pm 3.47^{c}$ & $29.06 \pm 0.36^{\mathrm{cd}}$ & $20.18 \pm 0.91^{c}$ & $44.01 \pm 0.41^{\mathrm{bd}}$ \\
\hline & $P$-value & 0.04 & 0.84 & 0.59 & 0.20 & 0.55 & 0.61 & 0.21 & 0.80 & 0.25 & 0.99 \\
\hline \multirow[t]{3}{*}{ 10th } & Females & $97.31 \pm 1.26^{c}$ & $100.17 \pm 1.18^{a}$ & $56.00 \pm 1.58^{d}$ & $13.73 \pm 0.25 e$ & $111.19 \pm 4.11^{\text {ad }}$ & $14.17 \pm 0.33^{d}$ & $55.70 \pm 2.37^{\mathrm{a}}$ & $23.47 \pm 0.53^{d}$ & $13.06 \pm 0.69^{c}$ & $36.51 \pm 0.61^{b}$ \\
\hline & Males & $96.76 \pm 1.18^{c}$ & $101.00 \pm 1.14^{a}$ & $55.34 \pm 1.94^{d}$ & $13.89 \pm 0.26^{b}$ & $109.02 \pm 3.87^{b}$ & $14.25 \pm 0.34^{d}$ & $55.28 \pm 4.96^{\mathrm{a}}$ & $24.27 \pm 0.51 \mathrm{e}$ & $13.41 \pm 1.30^{\mathrm{a}}$ & $37.34 \pm 0.59^{\mathrm{a}}$ \\
\hline & $P$-value ${ }^{1}$ & 0.67 & 0.45 & 0.67 & 0.45 & 0.61 & 0.75 & 0.83 & 0.05 & 0.47 & 0.10 \\
\hline \multirow[t]{3}{*}{$P$-value } & Females $^{2}$ & $<0.001$ & $<0.001$ & $<0.001$ & $<0.001$ & $<0.001$ & $<0.001$ & $<0.001$ & $<0.001$ & $<0.001$ & $<0.001$ \\
\hline & Males $^{2}$ & $<0.001$ & $<0.001$ & $<0.001$ & $<0.001$ & $<0.001$ & $<0.001$ & $<0.001$ & $<0.001$ & $<0.001$ & $<0.001$ \\
\hline & $P$-value ${ }^{1}$ & 0.30 & 0.14 & 0.90 & $<0.001$ & $<0.01$ & 0.02 & 0.48 & 0.20 & 0.73 & 0.25 \\
\hline
\end{tabular}

Abbreviation of indices: see Table 3, a,b,c,dMeans having different superscript letters within columns differ ( $p \leq 0.001)$. ${ }^{1}$ ANOVA test between females and males, ${ }^{2}$ ANOVA test between breeds for females and males 
The tenth group was that with the highest body size and the group with the smallest body size was the eighth in the case of females and the second in males. The difference between the $\mathrm{HaW}$ and $\mathrm{SC}$ is only $2 \mathrm{~cm}$ in the tenth $\mathrm{FCl}$ group but in the other two $\mathrm{FCl}$ groups, it was 14 and $22 \mathrm{~cm}$, respectively. The proportional index ( $\mathrm{Prl}$ ) indicates the existence of a difference between $\mathrm{HaW}$ and $\mathrm{BL}$, and both measurements were similar in the first, third, fifth, seventh and tenth $\mathrm{FCl}$ groups, corresponding with a square format $(\mathrm{HaW}=\mathrm{BL})$. Meanwhile, in the case of the other $\mathrm{FCl}$ groups, the length was greater than the height of the animals, with a rectangular format. Relative to bone development, the eighth and sixth groups were those with the largest bone development for DTI and RTCl, and DCl, respectively. In the case of both pelvic indices, LPI and TPI, the highest values were found in the sixth and eighth groups, respectively. The last index, relative proportionality of the thorax, was higher in the sixth group in both sexes than the other groups.

As we expected, significant differences $(P<0.001)$ for morphometric traits and body indices were found by analysis of variance among the eight groups of dogs studied in both sexes. The effect of sex in $\mathrm{FCl}$ groups was statistically significant $(P<0.05)$ in the majority of measurements. However, in the case of indices, it was only different in the first $\mathrm{FCl}$ group for $\mathrm{DCl}, \mathrm{RTCl}$ and $\mathrm{TPI}$, in the second $\mathrm{FCl}$ group for Prl and DTI, and in the eighth $\mathrm{FCl}$ group for Prl. As occurs in the case of breeds, the males had bigger mean values of biometric traits than females, which was even more marked in distance measurements (over $4 \mathrm{~cm}$ in some cases) and in the second $\mathrm{FCl}$ group.

\section{Application of discriminant analysis for breeds and FCl groups}

Table S3 shows the assignment percentages, higher in females than in males ( $90 \%$ vs. $86 \%$ ). Correct assignment ranged from 65.22 to $98.95 \%$ in females and 50.00 to $98.98 \%$ in males. When each breed was analysed separately, percentages of assignment over $95 \%$ were found in four breeds in the case of females (Spanish Sighthound, Spanish Water Dog, Canary Dogue and Ratonero Bodeguero Andaluz) and in three breeds in the case of males (Spanish Water Dog, Spanish Hound and Ratonero Bodeguero Andaluz). In contrast, we found some breeds which showed a greater number of errors in the assignment of individuals to their population: Perdiguero of Burgos (65.22\% in females), and Gos d'Atura (50\% in males).

When the animals are grouped according to their functional groups, the percentage of correct assignment of individuals to their functional group was $87.62 \%$ for females and $84.71 \%$ in males (Table 6).

The highest number of correct assignments was found in the Terrier Group (third $\mathrm{FCl}$ group) (>98\%) in both sexes, followed closely by the Molossian (second $\mathrm{FCl}$ group) in the case of females (94.96\%) and Hounds (tenth $\mathrm{FCl}$ group) in males (97.67\%).

The second step in the application of discriminant analysis was to obtain the Mahalanobis distances among the breeds and $\mathrm{FCl}$ groups (Figures 2 and 3). As regards breeds, the biggest distances were found between the Pyrenean Mastiff and Spanish Mastiff in comparison with the Ratonero Bodeguero Andaluz. On the other hand, the closest breeds according to the values obtained through the morphometric study were the Ibizan Hound and Spanish Sighthound. In addition, the Mahalanobis distances between groups highlighted a larger morpho-structural difference between the animals of the second (Molossoids) and third 
Table 6

Classification (percentage of accuracy ratio) for 709 females and 656 males of $8 \mathrm{FCl}$ groups by 15 morphometric variables

\begin{tabular}{|c|c|c|c|c|c|c|c|c|c|c|}
\hline FCl Groups & Sex & Percentage & $1 s t$ & 2nd & $3 r d$ & 5 th & 6th & 7th & 8th & 10th \\
\hline \multirow[t]{2}{*}{$1 s t$} & Females & 77.66 & 73 & 7 & 2 & 9 & 0 & 1 & 2 & 0 \\
\hline & Males & 74.39 & 61 & 5 & 3 & 6 & 3 & 2 & 2 & 0 \\
\hline \multirow[t]{2}{*}{ 2nd } & Females & 94.96 & 6 & 132 & 0 & 0 & 0 & 1 & 0 & 0 \\
\hline & Males & 91.04 & 9 & 122 & 0 & 0 & 0 & 2 & 1 & 0 \\
\hline \multirow[t]{2}{*}{$3 r d$} & Females & 98.95 & 0 & 0 & 94 & 1 & 0 & 0 & 0 & 0 \\
\hline & Males & 98.68 & 0 & 0 & 75 & 1 & 0 & 0 & 0 & 0 \\
\hline \multirow{2}{*}{ 5th } & Females & 85.78 & 0 & 0 & 2 & 193 & 5 & 1 & 3 & 21 \\
\hline & Males & 77.91 & 0 & 0 & 4 & 134 & 2 & 1 & 10 & 21 \\
\hline \multirow[t]{2}{*}{ 6th } & Females & 87.10 & 1 & 0 & 0 & 2 & 27 & 0 & 1 & 0 \\
\hline & Males & 93.10 & 0 & 0 & 0 & 1 & 27 & 1 & 0 & 0 \\
\hline \multirow[t]{2}{*}{ 7th } & Females & 56.52 & 9 & 0 & 0 & 1 & 0 & 13 & 0 & 0 \\
\hline & Males & 50.00 & 13 & 1 & 0 & 0 & 0 & 15 & 1 & 0 \\
\hline \multirow[t]{2}{*}{ 8th } & Females & 90.00 & 1 & 0 & 1 & 4 & 0 & 1 & 63 & 0 \\
\hline & Males & 88.64 & 1 & 0 & 1 & 7 & 1 & 0 & 78 & 0 \\
\hline \multirow[t]{2}{*}{ 10th } & Females & 83.33 & 4 & 0 & 0 & 3 & 0 & 0 & 0 & 35 \\
\hline & Males & 97.67 & 0 & 0 & 0 & 1 & 0 & 0 & 0 & 42 \\
\hline \multirow[t]{2}{*}{ Total } & Females & 87.62 & 94 & 139 & 99 & 213 & 32 & 17 & 69 & 56 \\
\hline & Males & 84.71 & 84 & 128 & 83 & 150 & 33 & 21 & 92 & 63 \\
\hline
\end{tabular}
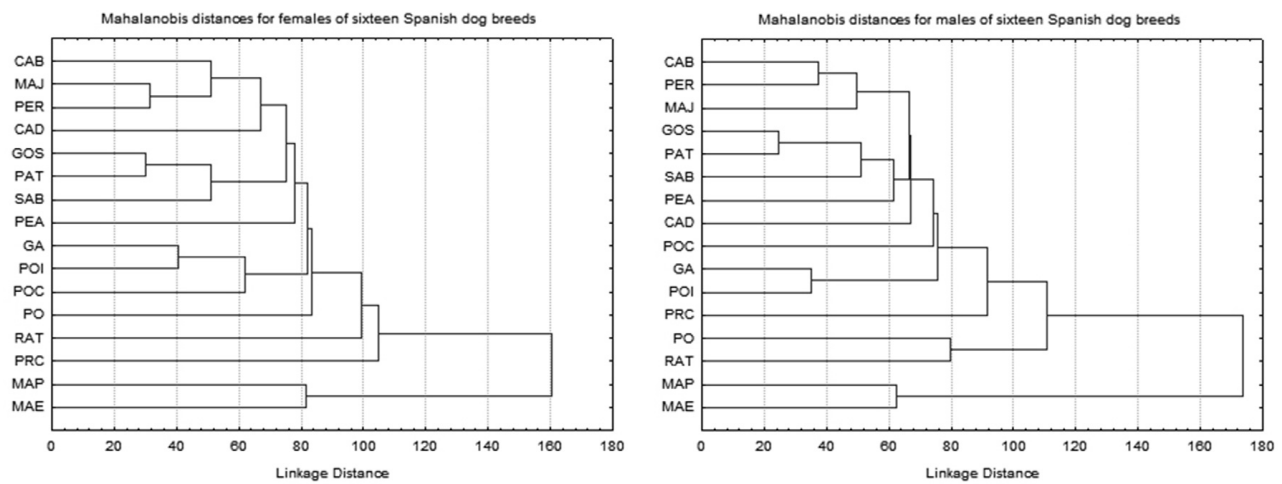

Abbreviation of breeds: see Table 1

Figure 2

Mahalanobis distances for 709 females and 656 males of sixteen Spanish dog breeds

(Terriers) $\mathrm{FCl}$ groups. However, the animals belonging to the first (Sheepdogs) and seventh (Pointing dogs) $\mathrm{FCl}$ groups were the closest. Both Mahalanobis distances were significant $(P \leq 0.001)$ (data no presented). 

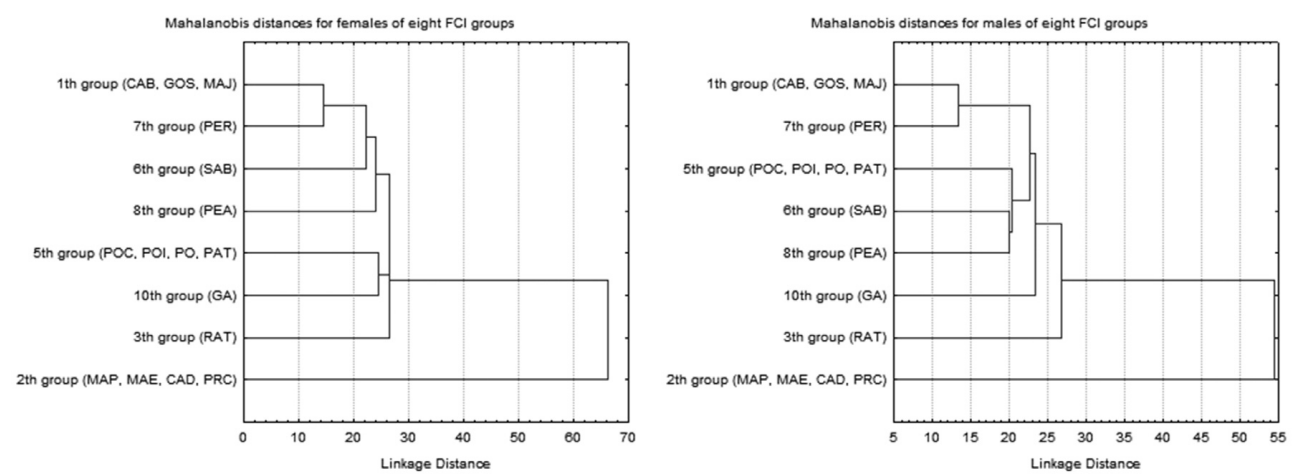

Abbreviation of breeds: see Table 1

\section{Figure 3}

Mahalanobis distances for 709 females and 656 males of eight $\mathrm{FCl}$ groups

The spatial location of the sixteen breeds according to the values obtained in the canonical analysis can be seen in Figure 4.

As for the two populations or breeds not officially recognized, the Orito and the Paternino Hound, only the former was located in the same spatial area of the dogs belonging to group 5 , in which this breed would be integrated according to their function. However, the spatial localization of the Partenino was among other Hound breeds and the Gos d'Atura.
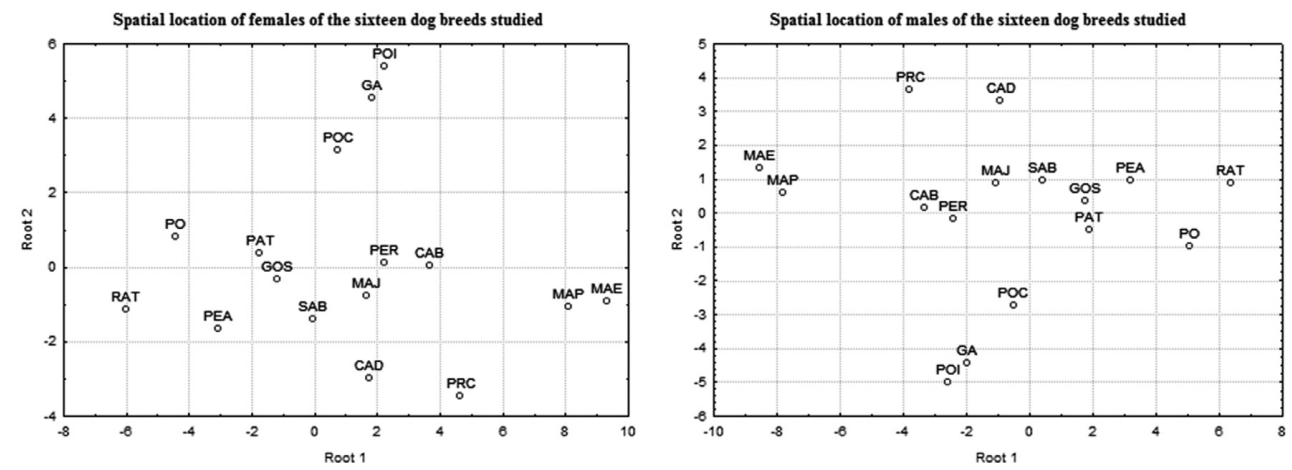

Abbreviation of breeds: see Table 1, Each of the axes refers to means of canonical values in the discriminant analyses.

Figure 4

Canonical representation of 709 females and 656 males in the sixteen Spanish dog breeds

\section{Discussion}

We evaluated the morphological characteristic of Spanish dog breeds and $\mathrm{FCl}$ groups in which they are included. The differentiation of canine breeds has been determined by natural selection and selection by human. Our results have shown that the chosen set of morphometric traits is suitable for characterizing individual dogs and for differentiating between 
breeds. Similar morphometric values can be found in those animals which belong to the same breed population, according their quantitative differences. Therefore, this implies the existence of a possible specific morphologic pattern for each population. The existence of this pattern is determined by quantitative information of each of the variables and indices, and by the relationships between them. Height at withers values found for the Orito Hound and Spanish Water Dog can be taken as an example (Table S1). These values were very similar; nevertheless, the values related to the length of the head were different in these two breeds. Thus, in this case is easy to check that the Orito Hound has a smaller head than the Spanish Water Dog, both quantitatively and proportionally.

The similar or different mean values in biometric traits could be due to the origin and function of the breeds. According with Morera et al. (1999) among the Spanish dog breeds, the degree of genetic differentiation was low, although only two breeds were coincident with our study (Spanish Sighthound and Water Dog). In other research by Jordana et al. (1991) a marked relationship, both morphological and biochemical, between Gos d'Atura and Ibizan Hound was found. In accordance with Jordana et al. (1992b) who found high genetic differences between some Spanish breeds (Pyrenean Mastiff, Spanish Hound and Ibizan Hound, Gos d'Atura and Ca de Bestiar), the high correct assignment percentage recorded in our study could be due to the great differentiation of breeds and could confirm the high discriminatory power of morphological measurements (Dossa et al. 2007). This differentiation between breeds is marked in a cluster tree, where formation of groups could correspond to the relationship between the different morphological characteristics and the function. The distribution of the breeds in the cluster shows the influence of two possible factors, function and breed origins. By the distribution in cluster trees and plotting through canonical variables, the Orito Hound shows a body conformation similar to other hound breeds, while Paternino is closer to Gos D'atura than other hounds. This fact could be due to the different uses, primarily for rabbit hunting in the case of Canarian, Ibizan and Orito Hounds, whilst Paternino was used to help deer and boar hunters.

The Spanish Greyhound is the only breed that appears with a slight uncertainty in its classification, since it is very close in shape and structure to the Canarian Hound, due to their common origin. This result agrees with those obtained by Jordana et al. (1992c) in nine Spanish dog breeds.

The relationship between morphology and function is commonly used and fixed in the standards of the dog breeds. The classification of the animals in each of the breeds studied was performed based on the data expressed in the Studbook of each one, and according to information revealed by their pedigrees. In the case of the Orito and Paternino Hounds, the animals were classified according to the criteria of their respective Breeders' Organizations.

Thanks to the information provided by morphometric variables, the quantified breed factor allows us to ascribe all the animals within the different groups of breeds, according to the morphologic differences shown by these animals. Therefore, each breed is a morphologically differentiated element, but they are grouped according to the $\mathrm{FCl}$ classification where each group contains dogs that were bred for a specific purpose.

In order to gather further knowledge about this approach, all the animals raised to carry out the same function need to be included in the same group, which are already classified by the $\mathrm{FCl}$ into ten different groups. 
These new groups of animals classified according to their function show high levels of correct assignment to the groups established by $\mathrm{FCl}$. If the existence of a morphologic pattern for each breed is accepted, then the existence of a common pattern related to the function (guard, shepherd, hunting, etc.) is also accepted, constituting a supra-breed pattern.

The fifth $\mathrm{FCl}$ group, the only group that included no recognized breeds, was the only one that showed a different distribution by cluster tree in both sexes. In males, this group is linked with the sixth and eighth $\mathrm{FCl}$ groups, and is close to the first and seventh $\mathrm{FCl}$ groups, while in females this group in linked with the tenth $\mathrm{FCl}$ group. This fact could be due to the similarity in the format of the Paternino Hound with Gos d'Atura in both sexes, and the Ibizan Hound and Spanish Sighthound in the case of females. This similarity between a hound and a sheepdog could relate to the Paternino's speciality of helping humans in deer and boar hunting, while the similarity between two other breeds, the Ibizan Hound and Spanish Sighthound, lies in the use of both breeds for rabbit hunting. Despite these errors in distribution of $\mathrm{FCl}$ groups in the cluster tree, this did not lead to any confusion in the assignment of individuals of the fifth $\mathrm{FCl}$ group with that group that included the Gos d'Atura, in both sexes. However, we tried repeating the cluster tree for the $\mathrm{FCl}$ group including the Paternino Hound in the $\mathrm{FCl}$ first group, due to its similarity with Gos d'Atura; however, due to the extension of this work, the data were not presented. The results of this new analysis showed that the fifth $\mathrm{FCl}$ group is linked to the tenth in both sexes and the first is linked to the seventh, which is exactly what occurs in the case of including the Paternino in the group of hounds. The differences between different groups of animals according to their function, with the exception of fifth $\mathrm{FCl}$ group, confirm the correct classification set up by the $\mathrm{FCl}$ to take into account quantitative and qualitative differences in the morphostructure of dogs belonging to different groups.

In conclusion, according to the information obtained from morphometric traits and functional indices, the sixteen Spanish dog breeds studied and eight functional groups are different but these differences are more marked between all groups than within groups. Thus, the morphological characteristics are similar, according to the function for which the breeds were bred. Therefore, the existence of a morphologic pattern is accepted for both breeds and functional groups.

Both breeds which have not yet been officially recognized, the Orito and Paternino Hound, must be included in the fifth and first $\mathrm{FCl}$ groups, respectively, because through morphometric traits, the similarity was greater with some breeds of each group than with breeds of the remaining groups. This fact will have its application when the Orito Hound is included in the fifth $\mathrm{FCl}$ group, when it is recognized and the word »hound" is eliminated from the name of the Paternino breed.

\section{References}

Capote J, Delgado JV, Fresno M, Camacho ME, Molina A (1998) Morphological variability in the Canary goat population. Small Rumin Res 27, 167-172

Crepaldi P, Negrini R, Milanesi E, Gorni C, Cicogna M, Ajmone-Marsan P (2001) Diversity in five goat populations of the Lombardy Alps: comparison of estimates obtained from morphometric traits and molecular markers. J Anim Breed Genet 118, 173-180

Dossa LH, Wollny C, Gauly M (2007) Spatial variation in goat populations from Benin as revealed by multivariate analysis of morphological traits. Small Rumin Res 73, 150-159 
González A, Luque M, Rodero E, González C, Aguilera R, Jiménez J, Sepúlveda N, Bravo S, Herrera M (2010) Use of Morphometric Variables for Differentiating Spanish Hound Breeds. Int J Morphol 29, 1248-1255

Herrera M, Rodero E, Gutierrez MJ, Peña F, Rodero JM (1996) Application of multifactorial discriminant analysis in the morphostructural differentiation of Andalusian caprine breeds. Small Rumin Res 22, 39-47

Jordana J, Piedrafita J, Sánchez A (1991) [Genetic variability in ten Spanish dog breeds]. Arch Zootec 40, 115129. [In Spanish]

Jordana J, Piedrafita J, Sánchez A (1992a) Genetic relationships in Spanish dog breeds. I. The analysis of morphological characters. Genet Sel Evol 24, 225-244

Jordana J, Piedrafita J, Sanchez A (1992b) Genetic relationships in Spanish dog breeds. II. The analysis of biochemical polymorphism. Genet Sel Evol 24, 245-263

Jordana J, Piedrafita J, Sanchez A, Puig P (1992c) Comparative F Statistics Analysis of the Genetic Structure of Ten Spanish Dog Breeds. J Hered 83, 367-374

Lanari MR, Taddeo H, Domingo E, Pérez Centeno M, Gallo L (2003) Phenotypic differentiation of exterior traits in local Criollo Goat Population in Patagonia (Argentina). Arch Tierz 46, 347-356

Latorre E, Uribe H, Martínez ME, Calderón C, de la Barra R (2011) Morphology Differentiation and Structural Functionality of Ewes Due to Incomplete Crossbreeding. Int J Morphol 29, 954-959

Macciotta NPP, Cappio-Borlino A, Steri R, Pulina G, Brandano P (2002) Somatic variability of Sarda goat breed analysed by multivariate methods. Livest Prod Sci 75, 51-58

Marrube G, Cano EM, Roldán DL, Bidinost F, Abad M, Allain D, Vaiman D, Taddeo H, Poli MA (2007) QTL affecting conformation traits in Angora goats. Small Rumin Res 71, 255-263

Morera L, Barba CJ, Garrido JJ, Barbancho M, de Andrés DF (1999) Genetic variation detected by microsatellites in five Spanish dog breeds. J Hered 90, 654-656

Morera Sanz L, Barba Capote CJ, Garrido Pavón JJ (2001) [Variability in Spanish dog breed detected by RAPD markers]. Arch Zootec 50, 379-382 [In Spanish]

Rodero E, Herrera M, Peña F, Molina A, Valera M, Sepúlveda N (2003) [Morpho-structural Model for Florida and Payoya Spanish Dairy Goats in Extensive (grazing) Systems]. Revista Científica, FCV-LUZ 13, 403-412. [In Spanish]

Traoré A, Tamboura HH, Kaboré A, Royo LJ, Fernández I, Álvarez I, Sangaré M, Bouchel D, Poivey JP, Francois D, Toguyeni A, Sawadogo L, Goyache F (2008a) Multivariate characterization of morphological traits in Burkina Faso sheep. Small Rumin Res 80, 62-67

Traoré A, Tamboura HH, Kabore A, Royo LJ, Fernández I, Álvarez I, Sangare M, Bouchel D, Poivey JP, Francois D, Sawadogo L, Goyache F (2008b) Multivariate analyses on morphological traits of goats in Burkina Faso. Arch Tierz 51, 588-600

Vargas S, Larbi A, Sánchez M (2007) Analysis of size and conformation of native Creole goat breeds and crossbreds used in smallholder agrosilvopastoral systems in Puebla, Mexico. Trop Anim Health Prod 39, 279-286

Vilà C, Savolainen P, Maldonado JE, Amorim IR, Rice JE, Honeycutt RL, Crandall KA, Lundeberg J, Wayne RK (1997) Multiple and Ancient Origins of the Domestic Dog. Science 276, 1687-1689

Yakubu A, Idahor KO, Haruna HS, Wheto M, Amusan S (2010) Multivariate analysis of phenotypic differentiation in Bunaji and Sokoto Gudali cattle. Acta Agric Slov 96, 75-80

Zaitoun IS, Tabbaa MJ, Bdour S (2005) Differentiation of native goat breeds of Jordan on the basis of morphostructural characteristics. Small Rumin Res 56, 173-182 